\title{
DIAGNOSTIK KESULITAN \\ BELAJAR MATEMATIKA SISWA SEKOLAH DASAR PADA MATERI OPERASI HITUNG BILANGAN BULAT NEGATIF
}

\author{
Nurjannah $^{1}$, Danial ${ }^{2}$, Fitriani $^{3}$ \\ nurjannah310807@gmail.com ${ }^{1}$ \\ IAI Muhammadiyah Sinjai, Jl. Sultan Hasanuddin No. 20 Sinjai ${ }^{1,2,3}$
}

\begin{abstract}
This study is a qualitative research that aims to describe and analyze the students' learning difficulties in mathematical operations of negative integers. The subjects of the study were two students of 286 SDN 286 Pasaka. Giving test (diagnostic tests) and interviewing were conducted to collect the data. The results of the study show that basically the learning difficulties experienced by the subject IS and subject $R V$ is same: the lack of understanding to the concept of negative integer operations. Due to the lack of understanding the concept, the subject is difficult to abstract, generalize and remember the concept or principle of operating negative integer operations. To overcome the learning difficulties experienced by students, the teacher must ensure students have mastered the prerequisite material, design ways of delivering teaching materials with effective communication and pay attention to family circumstances and social conditions of students.
\end{abstract}

Keywords: Characteristics of items, item difficulties, discrimination

\section{PENDAHULUAN}

Kesulitan belajar matematika siswa ditunjukkan oleh adanya hambatan-hambatan tertentu untuk mencapai hasil belajar (Rahman, dkk, 2015), sehingga pada akhirnya dapat menyebabkan prestasi belajar yang dicapainya berada dibawah semestinya. Sejalan dengan hal tersebut, Dowker (2009) berpendapat bahwa kesulitan belajar adalah kondisi yang menimbulkan hambatan dalam proses belajar seseorang. Hambatan ini menyebabkan orang 
tersebut mengalami kegagalan atau setidaknya kurang berhasil dalam mencapai tujuan belajar.

Penyebab terjadinya kesulitan menurut Paul (2014:448) kesulitan belajar yang dialami siswa disebabkan oleh beberapa hal yakni konsep yang dipelajari, metode mengajar yang digunakan oleh guru, pengetahuan yang telah dimiliki siswa atau kemampuan siswa yang mungkin kurang memadai. Kesulitan belajar matematika pada siswa berhubungan dengan kemampuan belajar yang kurang sempurna. Kekurangan tersebut dapat terungkap dari penyelesaian persoalan matematika yang tidak tuntas atau tuntas tetapi salah. Ketidaktuntasan tersebut dapat diduga karena kesalahan penggunaan konsep dan prinsip dalam menyelesaikan persoalan matematika yang diperlukan.

Kesulitan belajar merupakan terjemahan arti istilah bahasa Inggris yaitu learning disability. Terjemahan yang benar seharusnya adalah ketidakmampuan dalam belajar (learning artinya belajar, disability berarti ketidakmampuan), akan tetapi istilah kesulitan belajar digunakan karena dirasakan lebih optimistik (Abdurrahman, 2012:1).

Hal terpenting dalam proses pembelajaran adalah cara penyampaian informasi suatu bahan pelajaran, karena pembelajaran itu merupakan proses komunikasi, yaitu proses penyampaian informasi melalui saluran tertentu kepada si penerima. Pada proses komunikasi adakalanya siswa tidak dapat memahami simbol-simbol komunikasi yang disampaikan oleh gurunya. Hal inilah yang menjadi penyebab siswa mengalami kesulitan belajar (Suryanih, 2011).

Menurut (Parnawi, 2019: 98) aktifitas belajar bagi setiap individu tidak selamanya dapat berlangsung secara wajar. Kadang-kadang lancar, kadang-kadang tidak. Kadangkadang dapat dengan cepat menangkap apa yang dipelajari, kadang-kadang terasa amat sulit. Sedangkan menurut Ahmadi dan Widodo (2004:77) dalam keadaan dimana anak didik/siswa tidak dapat belajar sebagaimana mestinya, itulah yang disebut kesulitan belajar.

Kesulitan belajar tidak selalu disebabkan oleh faktor inteligensi yang rendah (kelainan mental), akan tetapi juga disebabkan oleh faktor-faktor noninteligensi. Dengan demikian, IQ yang tinggi belum tentu menjamin keberhasilan belajar (Parnawi, 2019: 99). Seperti diungkapkan oleh Syah (1999) bahwa kesulitan belajar tidak hanya menimpa siswa berkemampuan rendah saja, tetapi juga dialami oleh siswa yang berkemampuan tinggi. Selain pada siswa berkemampuan rendah dan tinggi, kesulitan belajar juga dapat dialami oleh siswa yang berkemampuan rata-rata, hal tersebut disebabkan oleh faktor- 
faktor tertentu yang menghambat tercapainya kinerja akademik yang sesuai harapan. Jadi belum tentu anak yang mengalami kesulitan belajar menandakan bahwa anak tersebut mempunyai IQ (Intelligence Quotient) rendah. Terkadang penyebab dari kesulitan belajar adalah karena siswa kurang memahami tidak tentang cara-cara belajar yang efektif.

Di setiap sekolah dalam berbagai jenis dan tingkatan pasti memiliki anak didik yang berkesulitan belajar. Setiap kali kesulitan belajar anak didik yang satu dapat diatasi, tetapi pada waktu yang lain muncul lagi kesulitan belajar anak didik yang lain. Hal tersebut dikarenakan adanya keberagaman individu tiap peserta didik dan kondisi lingkungan yang berbeda pula, sehingga timbullah permasalahan yang berbeda.

Dari berbagai definisi tentang kesulitan belajar yang dikemukakan oleh para ahli di atas, maka kesulitan belajar adalah keadaan dimana peserta didik tidak dapat belajar sebagaimana mestinya tentang logika mengenai bentuk, susunan, besaran dan konsepkonsep yang berhubungan satu dengan yang lain.

Terdapat banyak ahli yang mengemukakan penyebab terjadinya kesulitan belajar pada siswa. Salah satunya adalah seorang ahli yang berkebangsaan China. Wang (2009: 132) menyatakan beberapa penyebab kesulitan belajar siswa dalam pembelajaran matematika bisa terdiri dari faktor dari dalam diri siswa (intern factors) dan faktor dari luar siswa (extern factors). Faktor internal tersebut antara lain kelemahan fisik, mental, dan emosional; kebiasaan dan sikap-sikap yang salah (seperti malas belajar), atau tidak memiliki keterampilan dan pengetahuan dasar yang diperlukan (Suryanih, 2011). Sedangkan Faktor eksternal antara lain: kurikulum dan pelaksanaan pembelajaran yang tidak tepat, beban belajar yang terlalu berat, terlalu banyak kegiatan di luar jam sekolah, terlalu sering pindah sekolah, dan sebagainya.

Faktor-faktor tersebut sangat mempengaruhi siswa dalam menyerap bahan ajar yang disajikan. Masing-masing faktor memiliki intensitas pengaruh yang berbeda pada tiap siswa tergantung dari masalah yang dialami masing-masing siswa. Misalkan pada siswa tertentu mungkin metode pembelajaranlah yang menjadi faktor utama penyebab kesulitannya dalam belajar, akan tetapi pada siswa lain yang brokenhome misalnya, faktor emosional lah yang paling mempengaruhi kesulitan dalam belajar.

Menurut Paul (2014:448) kesulitan belajar yang dialami siswa disebabkan oleh beberapa hal yakni konsep yang dipelajari, metode mengajar yang digunakan oleh guru, pengetahuan yang telah dimiliki siswa atau kemampuan siswa yang mungkin kurang memadai. 
Kesulitan belajar menjadi hal yang banyak dikaji oleh peneliti dewasa ini. Hal ini terjadi karena kesulitan belajar membuat siswa tidak mampu untuk belajar sebagaimana mestinya. Salah satu penelitian tentang kesulitan belajar dilakukan oleh Imawati (2016) dimana hasilnya menunjukkan bahwa jenis kesulitan belajar yang dialami siswa adalah kesulitan dalam menggunakan rumus, kesulitan dalam menghitung desimal serta kesulitan dalam diri siswa sendiri. Adapun faktor yang menyebabkannya adalah kemampuan intelektual yang dimiliki siswa, cara belajar, motivasi belajar, kebiasaan belajar, konsentrasi belajar, kemampuan mengingat serta kesehatan tubuh.

Penelitian lain dilakukan oleh Noviantari (2016) dimana diperoleh hasil bahwa kesulitan yang dialami siswa adalah kesulitan untuk menyebutkan unsur-unsur, kesulitan dalam menganalisis soal dan menerapkan rumus. Adapun faktor yang menyebakan kesulitan belajar tersebut adalah ada dua yaitu faktor internal berupakurangnya persiapan belajar, kurangnya motivasi dan kurang pahamnya terhadap materi prasyarat. Sedangkan faktor eksternal meliputi suasana belajar di sekolah yang kurang mendukung.

Dalam pembelajaran matematika, Brueckner dan Bond (Yeo, 2009) mengelompokkan penyebab kesulitan belajar menjadi 5 faktor, yakni faktor fisiologis, faktor sosial, faktor emosional, faktor intelektual, dan faktor pedagogis. Faktor intelektual yang menjadi penyebab kesulitan belajar siswa umumnya adalah: a) siswa kurang berhasil dalam menguasai konsep, prinsip, dan algoritma, b) kesulitan mengabstraksi, menggeneralisasi, berpikir deduktif, dan mengingat konsep-konsep maupun prinsipprinsip, c) kesulitan dalam memecahkan masalah terapan atau soal cerita, dan d) kesulitan pada pokok bahasan tertentu saja.

Pendapat tersebut sejalan dengan pendapat Sholeh (1998) yang menyatakan bahwa siswa yang mengalami kesulitan belajar antara lain disebabkan oleh hal-hal sebagai berikut:a) siswa tidak bisa menangkap konsep dengan benar, b) siswa tidak mengerti arti lambang- lambang, c) siswa tidak dapat memahami asal- usul suatu prinsip, d) siswa tidak lancar menggunakan operasi dan prosedur, dan e) Ketidaklengkapan pengetahuan.

Sedangkan menurut Wang (2009)bahwa yang menjadi penyebab siswa mengalami kesulitan belajar matematika ialah kesulitan siswa dalam: a) kemampuan dalam mengembangkan konsep-konsep, b) kemampuan mengembangkan pemahaman matematika, c) kemampuan mengembangkan keterampilan (matematika), d) kemampuan dalam memecahkan soal, dan e) kemampuan mengembangkan sikap menghargai dan sikap lain yang menguntungkan (seperti berdiskusi, keaktifan dalam belajar bersama, dsb.) 
Menurut (Widdiharto, 2008) dalam pembelajaran matematika, kesulitan siswa dari segi intelektual dapatterlihat dari kesalahan yang dilakukan siswa pada langkah-langkah pemecahan masalah soal matematika yang berbentuk uraian, karena siswa melakukan kegiatan intelektual yang dituangkan pada kertas jawaban soal yang berbentuk uraian tersebut. Beberapa ahli menggolongkan jenis-jenis kesalahan siswa dalam menyelesaikan soal matematika yakni: kesalahan pemahaman konsep; kesalahan penggunaan operasi hitung; algoritma yang tidak sempurna; dan kesalahan karena mengerjakan serampangan/ceroboh.

Berdasarkan paparan tersebut di atas dapat disimpulkan bahwa secara garis besar kesulitan yang dialami siswa dapat berupa ketidakmampuan dalam menerima konsep dengan benar, kesulitan memahami materi pembelajaran, kesulitan dalam menggunakan prinsip dan aturan serta kurangnya pengetahuan dan keterampilan dalam menyelesaikan persoalan matematika.

Setelah melakukan wawancara pada guru matematika di SD 286 Pasaka, diperoleh informasi bahwa materi yang sering dikeluhkan oleh siswa adalah materi operasi hitung bilangan negatif. Karena materi ini memerlukan pemahaman konsep yang mendalam untuk memudahkan siswa untuk melakukan operasi yang dimaksudkan. Untuk itu, diperlukan sebuah analisis untuk mengetahui penyebab kesulitan belajar yang dialami siswa pada materi operasi hitung bilangan negatif.

\section{METODE PENELITIAN}

Penelitian ini merupakan penelitian kualitatif. Subjek penelitian ini terdiri dari dua orang siswa kelas IV di SD Negeri 286 Pasaka masing-masing berinisial IS dan RV. Kedua subjek tersebut berjenis kelamin laki-laki dengan kemampuan matematika relatif sama, dan berkemampuan komunikasi baik. Metode pengumpulan data yangdigunakan ada dua yakni metode tes berupa tes diagnostik dan wawancara. Wawancara ini dilakukan untuk menggali informasi terkait hasil jawaban pada tugas pemecahan masalah yang dikerjakan sebelumnya. Tes diagnostik berisi tentang soal-soal pemecahan masalah operasi hitung bilangan bulat negatif yang terdiri dari empat nomor sesuai dengan jumlah operasi hitung bilangan bulat negatif. Tes diagnostik diberikan sebanyak dua kali pada waktu yang berbeda.

Data yang diperoleh dari hasil wawancara perlu untuk dicek validitasnya. Teknik yang digunakan untuk mengecek validitas data dalam penelitian ini adalah teknik triangulasi 
waktu yakni pengecekan validitas terhadap data pada wawancara pertama dengan data yang diperoleh pada wawancara kedua.

Berikut soal yang digunakan dalam penelitian ini.

Selesaikanlah soal-soal berikut dengan baik dan benar!

1. $16+(-15)=\cdots$

2. $-2.3-15=\cdots$

3. $14 \times(-10)=\cdots$

4. $-20 \div(-5)=\cdots$

- Selamat bekerja -

Gambar 1. Soal operasi bilangan bulat

\section{HASIL PENELITIAN DAN PEMBAHASAN}

\section{Kesulitan Belajar Matematika Subjek IS pada Materi Operasi Hitung Bilangan Bulat Negatif}

Berikut ditampilkan lembar jawaban Subjek IS dalam menyelesaikan soal operasi hitung bilangan bulat.

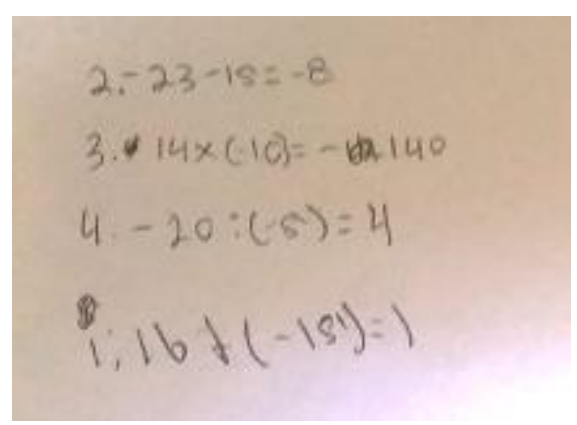

Gambar 2. Lembar Jawaban Subjek IS

Saat diberikan tes diagnostik kepada subjek IS, terlihat bahwa subjek IS pertama kalimengerjakan soal tentang pengurangan bilangan bulat negatif dengan soal diagnostik tersebut adalah $-23-15=\cdots$. Subjek IS tampak kebingungan dengan menggaruk-garuk kepala. Setelah beberapa waktu, subjek IS mulai mencari jawaban dengan melakukan penjumlahan bersusun menuliskan hasil dari tes tersebut. Akan tetapi jawaban yang diberikan kurang tepat. Terdapat kesalahan pada perhitungan dimana sedangkan jawaban dari subjek IS adalah -8. Berdasarkan hasil wawancara terhadap subjek IS diperoleh 
informasi bahwa menurut pemahaman IS negatif dua puluh tiga bertemu dengan negatif lima belas maka langsung dikurangkan sehingga dua puluh tiga dikurang lima belas adalah delapan. Adapun tanda negatif di depan angka delapan diperoleh dengan menyesuaikannya dengan angka negatif di depan dua puluh tiga.

Tabel 1. Potongan Wawancara dengan Subjek IS Pada Soal Pengurangan

\begin{tabular}{ll}
\hline P03 & Kenapa bisa dapat hasilnya begitu? \\
I03 Karena kalau minus ketemu minus langsung saja dikurang jadi minus dua puluh \\
& $\begin{array}{l}\text { tiga dikurang lima belas hasilnya minus delapan } \\
\text { P04 }\end{array}$ Yakin? \\
I04 & Iye, yakin. \\
\hline
\end{tabular}

Selanjutnya, subjek IS memilih untuk mengerjakan soal tentang perkalian bilangan bulat negatif dimana soalnya adalah $14 \times(-10)=\cdots$. Saat menjawab soal kedua, subjek IS terlihat lebih percaya diri. Subjek IS melakukan perkalian bersusun dan memperoleh hasil yakni -140. Berdasarkan hasil wawancara terhadap subjek IS diperoleh informasi bahwa menurut pemahaman IS, jika terdapat soal perkalian bilangan bulat negatif maka langsung dilakukan perkalian seperti biasanya kemudian hasilnya diberikan tanda negatif.

Tabel 2. Potongan Wawancara dengan Subjek IS Pada Soal Perkalian

\begin{tabular}{l}
\hline P06 Kenapa bisa dapat hasilnya negatifseratus empat puluh? \\
I06 Karena memang begitu bu, kalau positif dikali negatif hasilnya negatif jadi \\
minus serratus empat puluh hasilnya
\end{tabular}

Selanjutnya, subjek IS memilih untuk mengerjakan soal tentang pembagian bilangan bulat negatif dimana soalnya adalah $-20 \div(-5)=\cdots$. Saat menjawab soal tersebut, subjek IS terlihat sangat tenang. Subjek IS melakukan pembagian bersusun dan memperoleh hasil yakni 4. Berdasarkan hasil wawancara terhadap subjek IS diperoleh informasi bahwa menurut pemahaman IS, jika terdapat soal pembagian bilangan bulat negatif maka langsung dilakukan pembagian seperti biasanya kemudian tandanya berubah menjadi positif karena negatif bertemu dengan negatif hasilnya adalah positif. 
Tabel 3. Potongan Wawancara dengan Subjek IS Pada Soal Pembagian

\begin{tabular}{ll}
\hline P08 & Kenapa bisa dapat hasilnya empat? \\
I08 & Karena memang begitu bu, kalau minus dibagi minus hasilnya positif bu jadi \\
& empat hasilnya ini bu. \\
P09 Bukan minus empat? & I09 \\
\hline
\end{tabular}

Pada soal yang terakhir, subjek IS mengerjakan soal tentang penjumlahan bilangan bulat negatif dimana soalnya adalah $16+(-15)=\cdots$. Saat menjawab soal tersebut, subjek IS terlihat sangat tenang. Subjek langsung menuliskan jawaban dengan angka 1. Setelah dilakukan wawancara diperoleh informasi bahwa pemahaman subjek tentang penjumlahan bilangan bulat positif yakni jika angka positif dijumlahkan dengan angka negatif, maka sama saja dengan mengurangi angka pertama dengan angka kedua sementara tandanya akan bergantung pada angka terbesar. Dalam hal ini angka terbesar adalah positif sehingga hasilnya adalah positif satu.

Tabel 4. Potongan Wawancara dengan Subjek IS Pada Soal Penjumlahan

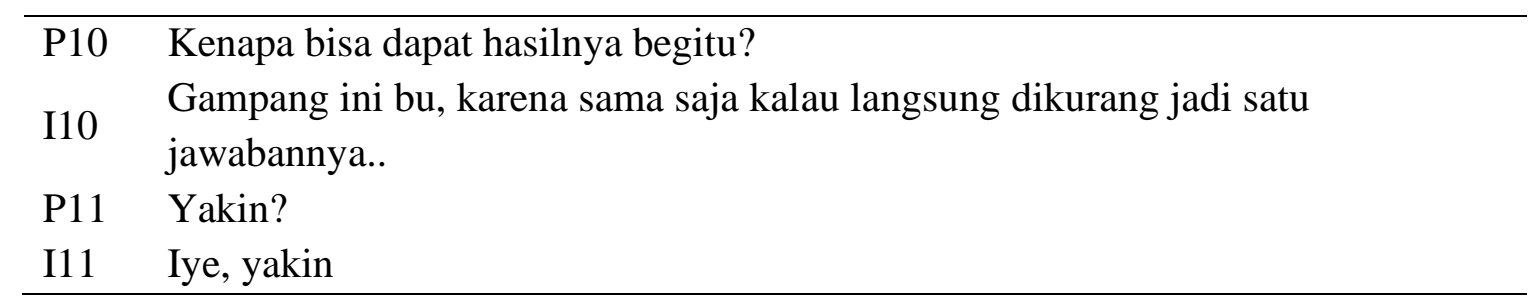

Berdasarkan hasil tes diagnostik dan wawancara yang dilakukan pada subjek IS maka terlihat bahwa pada dasarnya subjek IS sudah mampu melakukan perhitungan pada semua soal kecuali pada soal pengurangan bilangan bulat negatif yang diberikan. Hal ini terlihat dari benarnya perhitungan subjek pada semua operasi hitung tersebut. Akan tetapi, yang membuat jawaban subjek IS salah pada operasi hitung pengurangan adalah kesalahan menguasai konsep serta sulitnya mengabstraksi, menggeneralisasi, berpikir deduktif, dan mengingat konsep-konsep maupun prinsip-prinsip operasi hitung bilangan bulat negatif. Hal ini sesuai dengan teori yang dikemukakan oleh Brueckner dan Bond (Yeo, 2009) tentang penyebab kesulitanbelajar yang dialami siswa. 


\section{Kesulitan Belajar Matematika Subjek RV pada Materi Operasi Hitung Bilangan Bulat Negatif}

Berikut ditampilkan lembar jawaban Subjek IS dalam menyelesaikan soal operasi hitung bilangan bulat.

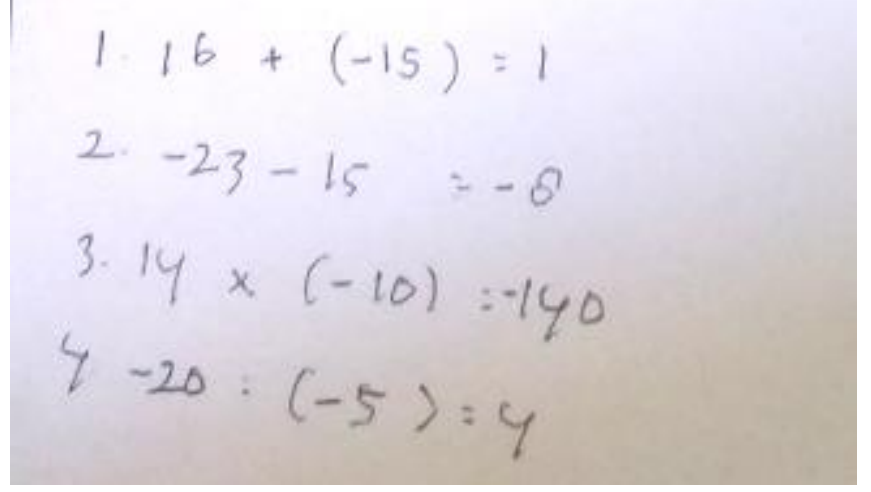

Gambar 3. Lembar Jawaban Subjek RV

Ketika subjek RV diberikan tes diagnostik, subjek RV pertama kalimengerjakan soal tentang penjumlahan bilangan bulat negatif dimana soalnya adalah $16+(-15)=\cdots$. Saat mengerjakan soal, subjek RV tampak tenang dan tidak menunjukkan ekspresi kegelisahan. Subjek RV menuliskan angka 1 sebagai jawaban dari soal yang sama dengan soal yang diberikan kepada subjek IS. Saat diwawancara, subjek RV menjelaskan bahwa ketika mengerjakan soal tersebut subjek RV langsung mengurangkan angka enam belas dengan lima belas sehingga hasilnya adalah satu. Hal ini ia lakukan karena menurut pemahaman subjek RV, ketika tanda positif bertemu dengan negatif maka otomatis akan berubah menjadi negatif.

Tabel 5. Potongan Wawancara dengan Subjek RV Pada Soal Penjumlahan

\begin{tabular}{ll}
\hline P01 & Kenapa bisa dapat hasilnya begitu? \\
R01 & Karena kalau positif ditambah dengan negatif tandanya langsung berubah jadi \\
& negatif. \\
P02 & Maksudnya? \\
R02 & $\begin{array}{l}\text { Sama saja kalau langsung dikurang itu enam belas dikurang lima belas jadi } \\
\text { hasilnya } 1 \text { bu. }\end{array}$ \\
\hline
\end{tabular}

Subjek RV kemudian mengerjakan soal tentang pengurangan bilangan bulat negatif dengan soal diagnostik tersebut adalah $-23-15=\cdots$. Subjek RV nampak mulai kebingungan. Setelah beberapa waktu, subjek RVmenjawab dengan -8. Berdasarkan hasil wawancara terhadap subjek RV diperoleh informasi bahwa menurut pemahaman RV negatif dua puluh tiga bertemu dengan negatif lima belas maka langsung dikurangkan sehingga dua 
puluh tiga dikurang lima belas adalah delapan. Adapun tanda negatif di depan angka delapan diperoleh dengan mengikuti tanda pada angka terbesar dalam hal ini adalah dua puluh tiga sehingga jawabannya adalah negatif 8 .

Tabel 6. Potongan Wawancara dengan Subjek RV Pada Soal Pengurangan

\begin{tabular}{ll}
\hline P04 & Kenapa bisa dapat negatif delapan? \\
R04 Anu bu, kalau negatif ketemu sama negatif langsung dikurang saja bu. Jadi \\
& negatif dua puluh tiga dikurang lima belas itu hasilnya delapan. \\
P05 Yakin? & \\
P05 Iye, yakin. \\
P06 Coba dilihat baik-baik, siapa tau ada yang salah. \\
R06 Tidak bu, delapan memang hasilnya.
\end{tabular}

Selanjutnya, subjek RV mengerjakan soal tentang perkalian bilangan bulat negatif dimana soalnya adalah $14 \times(-10)=\cdots$. Saat menjawab soal tersebut, subjek RV terlihat sangat tenang. Subjek RV melakukan perkalian bersusun dan memperoleh hasil yakni -140. Berdasarkan hasil wawancara terhadap subjek RV diperoleh informasi bahwa menurut pemahaman RV, jika terdapat soal perkalian bilangan bulat negatif maka langsung dilakukan perkalian seperti biasanya kemudian hasilnya diberikan tanda negatif saja.

Tabel 7. Potongan Wawancara dengan Subjek RV Pada Soal Perkalian

\begin{tabular}{ll}
\hline P07 & Kenapa bisa dapat hasilnya negatif seratus empat puluh? \\
I07 Karena memang begitu bu, kalau positif dikali negatif hasilnya negatif jadi \\
minus serratus empat puluh hasilnya
\end{tabular}

Terakhir, subjek RV mengerjakan soal tentang pembagian bilangan bulat negatif dimana soalnya adalah $-20 \div(-5)=\cdots$. Saat menjawab soal tersebut, tidak ada ekspresi yang nampak pada wajah subjek RV. Subjek RV melakukan pembagian bersusun dan memperoleh hasil yakni 4. Berdasarkan hasil wawancara terhadap subjek RV diperoleh informasi bahwa menurut pemahaman RV, jika terdapat soal pembagian bilangan bulat negatif maka langsung dilakukan pembagian seperti biasanya kemudian tandanya berubah menjadi positif karena negatif bertemu dengan negatif hasilnya positif. 
Tabel 8. Potongan Wawancara dengan Subjek RV Pada Soal Pembagian

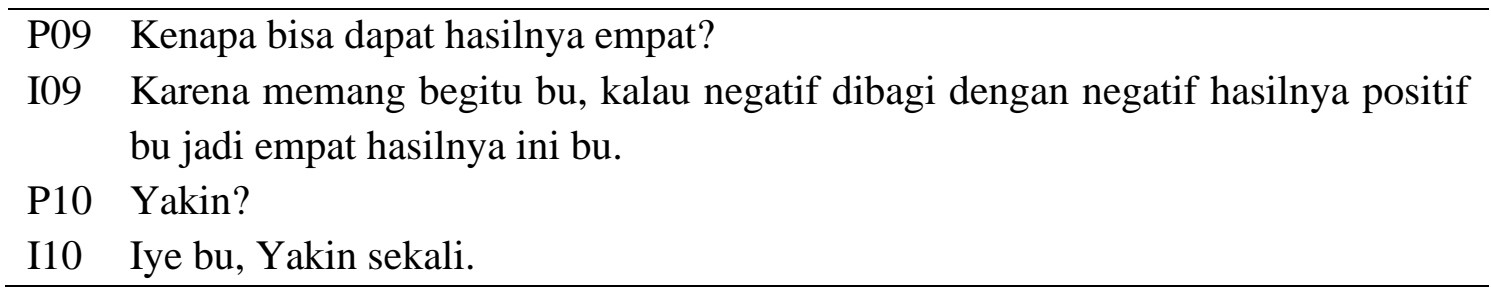

Berdasarkan hasil tes diagnostik dan wawancara yang dilakukan pada subjek RV maka terlihat bahwa pada dasarnya subjek RV sudah mampu menyelesaikan operasi hitung bilangan bulat negatif pada semua soal kecuali pada soal pengurangan bilangan bulat negatif yang diberikan. Hal ini terlihat dari benarnya perhitungan subjek pada semua operasi hitung tersebut. Akan tetapi, yang membuat jawaban subjek RVsalah pada operasi hitung pengurangan adalah kesalahan menguasai konsep serta sulitnya mengabstraksi, menggeneralisasi, berpikir deduktif, dan mengingat konsep-konsep maupun prinsipprinsip operasi hitung bilangan bulat negatif. Hal ini sesuai dengan teori yang dikemukakan oleh Brueckner dan Bond (Yeo, 2009) tentang penyebab kesulitanbelajar yang dialami siswa.

\section{KESIMPULAN}

Berdasarkan hasil dan pembahasan diatas, maka dapat disimpulkan bahwa pada dasarnya kesulitan belajar yang dialami oleh subjek IS dan subjek RV sama yakni kurangnya pemahaman konsep pada operasi hitung bilangan bulat negatif. Karena kurangnya pemahaman konsep ini sehingga subjek sulit untuk mengabstraksi, menggeneralisasi serta mengingat konsep atau prinsip operasi hitung bilangan bulat. Untuk mengatasi kesulitan belajar yang dialami siswa, guru hendaknya memperhatikan hal-hal krusial seperti ketidakmampuan dalam menerima konsep dengan benar, kesulitan memahami materi pembelajaran, kesulitan dalam menggunakan prinsip dan aturan serta kurangnya pengetahuan dan keterampilan dalam menyelesaikan persoalan matematika. Oleh karena itu, guru harus memastikan siswa telah menguasai materi prasyarat, mendesain cara penyampaian bahan ajar dengan komunikasi yang efektif serta memperhatikan keadaan keluarga dan keadaan sosial siswa sehingga kedepannya tidak terjadi lagi kesulitan belajar pada diri siswa. 


\section{DAFTAR PUSTAKA}

Ahmadi, A. \& Widodo, S. (2004). Psikologi Belajar. Jakarta: Rineka Cipta.

Dowker, A. 2009. What Works for Children with Mathematical Difficulties?.University of Oxford. (online), (www.standards.dcsf.gov.uk).

Imawati, Theresia. (2016). Diagnosis Kesulitan Belajar Matematika Siswa Kelas VIII E SMP Negeri 2 Jatinom pada Materi Luas dan Keliling Lingkaran. Skripsi. Universitas Sanata Dharma: Yogyakarta.

Noviantasari, I. Margarita. (2016). Diagnosis dan remediasi Kesulitan Belajar Siswa Kelas VIII A SMP Kanisius Sleman Tahun Ajaran 2015/2016 pada Pokok Materi Kubus dan Balok. Skripsi. Universitas Sanata Dharma: Yogyakarta.

Paul, M. \& Haningpai, N. (2014). The Nature of Misconceptions and Cognitive Obstacles Faced by Secondary School Mathematics Students in Understanding Probability: A Case Study of Selected Polokwane Secondary Schools. Mediterranean Journal of Social Sciences, 5(8), 446-455.

Parnawi, A. (2019). Psikologi Belajar. Yogyakarta: Budi Utama.

Rahman, U. (2015). Pengaruh Kecemasan dan Kesulitan Belajar Matematika Terhadap Hasil Belajar Matematika Pada Siswa Kelas X MA Negeri 1 Watampone Kabupaten Bone. Jurnal Matematika dan Pembelajaran. 3(1), 85-102.

Sholeh, M. (1998). Pokok- pokok Pengajaran Matematika di Sekolah. Jakarta: Departemen Pendidikan dan Kebudayaan RI. (online)http://idb4.wikispaces.com.

Suryanih. 2011. Diagnosis Kesulitan Belajar Matematika Siswa Dan Solusinya Dengan Pembelajaran Remedial. Skripsi. Universitas Islam Negeri Syarif Hidayatullah Jakarta. [Online]. http://docplayer.info/32533169-Diagnosis-kesulitan-belajarmatematika-siswa-dan-solusinya-dengan-pembelajaran-remedial-penelitiandeskriptif-analisis-di-man-7-jakarta.html.

Syah, M. (1999). Psikologi Pendidikan dengan Pendekatan Baru. Bandung: PT. Remaja Rosdakarya.

Wang, G., et al. (2009). Case Study on Improving High School Student With Learning Difficulties In Mathematics. International Journal of Mathematics Educations. 2(2), 122-133.

Widdiharto, R. (2008). Diagnosis Kesulitan Belajar Matematika SMP dan Alternatif Proses Remidinya, Paket Fasilitasi Pemberdayaan KKG/MGMP Matematika. Yogyakarta: Depdiknas.

Yeo, K.K.J. (2009). Students' Difficulties In Solving Non-Routine Problem. International Journal of Mathematics Educations. 10(--).1-30. 